\title{
Climate Change Variability Trends and Implications for Freshwater Resources in Pakistan's Eastern Hindu Kush Region
}

\author{
Nasir Hussain', Shaukat Ali'*, Azhar Hussain², Salar Ali³, Sher Wali Khan, \\ Ghulam Raza', Qamar Abbas', Iqtidar Hussain', Muhammad Hussain² \\ ${ }^{1}$ Department of Environmental Sciences, Karakoram International University, \\ Gilgit-Baltistan 15100, Gilgit, Pakistan \\ ${ }^{2}$ Department of Agriculture and Food Technology, Karakoram International University, \\ Gilgit-Baltistan 15100, Pakistan \\ ${ }^{3}$ Key Laboratory of Watershed Geographic Sciences, Institute of Geography and Limnology, \\ Chinese Academy of Sciences, 73 East Beijing Road, Nanjing 210008, China \\ ${ }^{4}$ Department of Biological Sciences, Karakoram International University, \\ Gilgit-Baltistan 15100, Gilgit, Pakistan
}

Received: 17 May 2017

Accepted: 18 July 2017

\begin{abstract}
Due to climate change, the world average surface temperature has increased $0.3-0.6^{\circ} \mathrm{C}$ over the past 100 years. The northern belt of Pakistan holds the largest storage of freshwater (ice and snow) after the polar region, and provides water to the downstream population for agriculture plus domestic and hydropower resources. This study focuses on a possible explanation for the seemingly declining behavior of Darkut Glacier using evidence from ground observation and climate station data in Yasin and Gupis valleys in northern Pakistan. We analyzed data obtained from two stations includes the Water and Power Development Authority of Pakistan (WAPDA, 1995-2010) and the Pakistan Meteorology Department (PMD, 1986-2015). Results of both climate station data depicted an increase in total precipitation and a decrease in winter and spring seasons. The study also highlighted an increase in mean minimum and maximum temperatures, particularly in winter and spring. Similarly, the trend of solar radiation also has decreased. Therefore, enhanced snout fluctuation and the melting rate of Darkut occurred during the study period. All of these changes have had a negative impact on the snout of the glacier, which has retreated $6 \mathrm{~m}$ during 2013 and 2016, and a lake has formed behind the terminal moraine.
\end{abstract}

Keywords: climate change, temperature, precipitation, solar radiation, eastern Hindu Kush, Darkut Glacier

*e-mail: dr.shaukat@kiu.edu.pk 


\section{Introduction}

Earth's climate has been evolving over millennia, but in the last two centuries the change in climate has been unique due to the development of Greenhouse gases [1]. Global climate change indicates that our planet's climate has changed as a whole through shifts of average weather patterns over a period of 30 years or so [2]. According to the Intergovernmental Panel on Climate Change, Fifth Assessment Report (IPCC-AR5), the global average temperature has increased by $0.85^{\circ} \mathrm{C}\left(0.65-1.06^{\circ} \mathrm{C}\right)$ over the period of $1800-2012$, relative to $1961-1990$ (IPCC, 2013), and $0.74-18^{\circ} \mathrm{C}$ has been detected during the last 100 years (1906-2005) [3].

The Hindukush-Karakorum-Himalaya $(\mathrm{HKH})$ is an ensemble of mountain ranges stretching east to west over $2,000 \mathrm{~km}$, containing around $60,000 \mathrm{~km}^{2}$ of glaciers and perennial surface ice in varying climatic regimes [4]. The high mountains of South Asia covering the (HKH) belt have been described as the "Water Tower of Asia" due to their significant role in feeding the major rivers of southern Asia [5]. Most of the glaciers in the HKH region have been diminishing and losing their mass since 1950, but the observed variations are not regionally consistent [6-8]. According to Rasul and Chaudhry [9], on the whole, HKH mountain terrain ice and snow coverage is now declining must faster than ever. In the mountain areas global warming effect on the cryosphere is clear in a reduced snow cover period and declines or contracts mountain glaciers [10]. The temperature of the $\mathrm{HKH}$ region has warmed by approximately $1.5^{\circ} \mathrm{C}$, which is almost twice the amount in other parts of Pakistan $\left(0.76^{\circ} \mathrm{C}\right)$ in the last 30 years [11]. A significant increase in the temperature of the $\mathrm{HKH}$ region is expected to impact snow cover dynamics, which in turn will affect seasonal flow variations [12].

Solar radiation drives many surface processes, including snow, glacier melt, and evaporation [13], that have consequences in near-surface air temperature changes. The diurnal temperature range (DTR), which is described as the variation between daily minimum and maximum temperatures, is useful for studying the counteracting effects of shortwave and long wave radioactive forcing because the diurnal minimum temperature is closely linked to long-wave radiation, whereas the diurnal maximum temperature is predominantly determined by shortwave radiation [14].

The climate and topography of the mountainous area have caused strong variations in glacier behaviour, and it has become too complex to understand the climate change impacts in the HKH region [15], where there is also the problem of scarcity of meteorological, hydrological, and glaciological data due to difficult terrain [16]. At present, limited work has been conducted to account for glacier fluctuations in response to changing climate, and few studies are available in the HKH region. The Gilgit sub-basin of UIB (between 35.8-37-E and 72.5-74.4-N) includes the eastern part of the Hindu Kush Range and drains south eastward into the Indus River. The drainage area of the basin corresponds to more than $12,000 \mathrm{~km}^{2}$ with an elevation range of 1481-7134 $\mathrm{m}$ (a. s. 1). The Gilgit basin receives its precipitation from both summer monsoon system and westerly disturbances [17]. The Gilgit basin was selected as the study area within the Upper Indus Basin (UIB). No detailed study has been conducted so far in Darkut Glacier, Yasin Valley GilgitBaltistan.

It is important to know about glacier behavior in the study area under the climate change scenario because glaciers are important sources of fresh water for the inhabitants of the mountainous region and also to downstream populations for multiple purposes, including domestic, agricultural, and hydroelectric power production. Therefore, the present research focused on evaluating the impact of climate change - especially on low-lying glaciers - and their impact in downstream areas
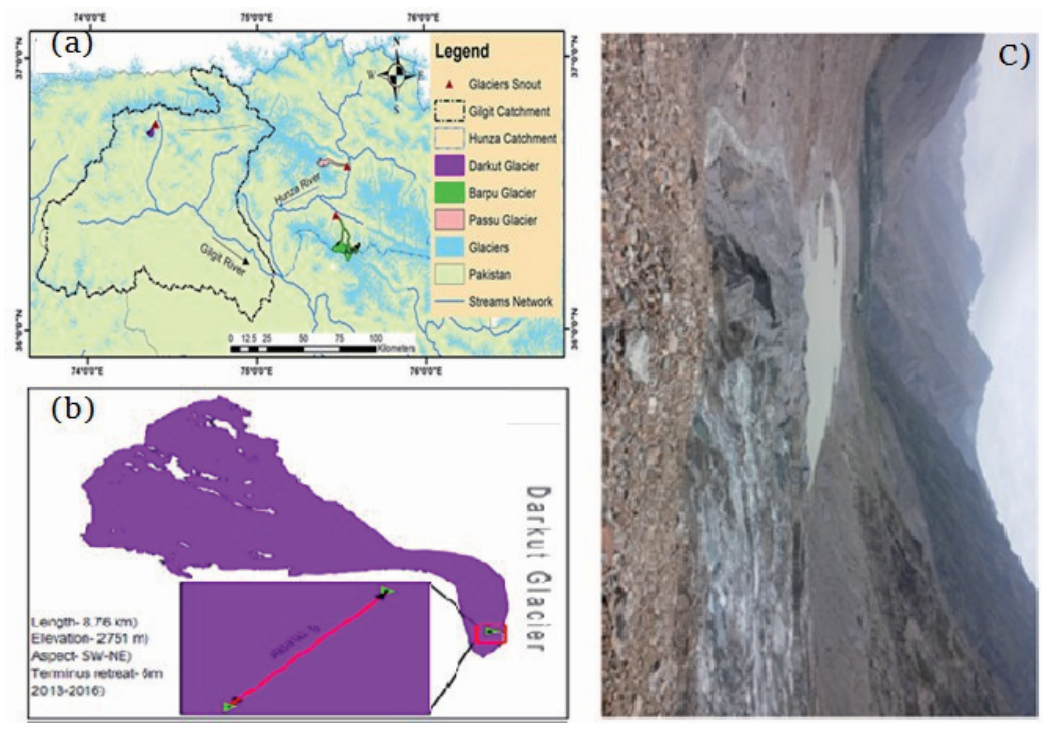

Fig. 1. Behavior of Darkut Glacier in the study area. 
in the eastern Hindu Kush that may help to explain the present status and future trends of glaciers.

\section{Material and Methods}

Darkut glacier is situated in Yasin Valley in northern Pakistan $\left(36.64382^{\circ} \mathrm{N}\right.$ and $\left.73^{\circ} 40027 \mathrm{E}\right)$ (Fig. 1a).The field survey was carried out between 2013 and 2016 and the topography of Darkut glacier was studied. During field work we used GPS to find the coordinates of the snout and a digital camera to take on-site glacier pictures. We obtained daily climate data (temperature, precipitation, and solar radiation) from WAPDA (1995-2010) and PMD (1986-2015; because the WAPDA station was installed at Yasin in 1995, past climate data are not available). The study area covers two climate stations - one automatic weather climate station of WAPDA at Yasin at 3,150 m a.s.l., while the PMD climate station was at Gupis Valley. Climate data for the last 16 years were analyzed to find trends of maximum temperature, minimum temperature, precipitation, and incidence of solar radiation along the study area. A regression equation was applied to find the trend of each parameter. Temperature data of each month were classified for annual and seasonal bases, while precipitation data were analyze taking as monthly and total annual precipitation and the solar radiation on the basis of highest, lowest, and average for each month.
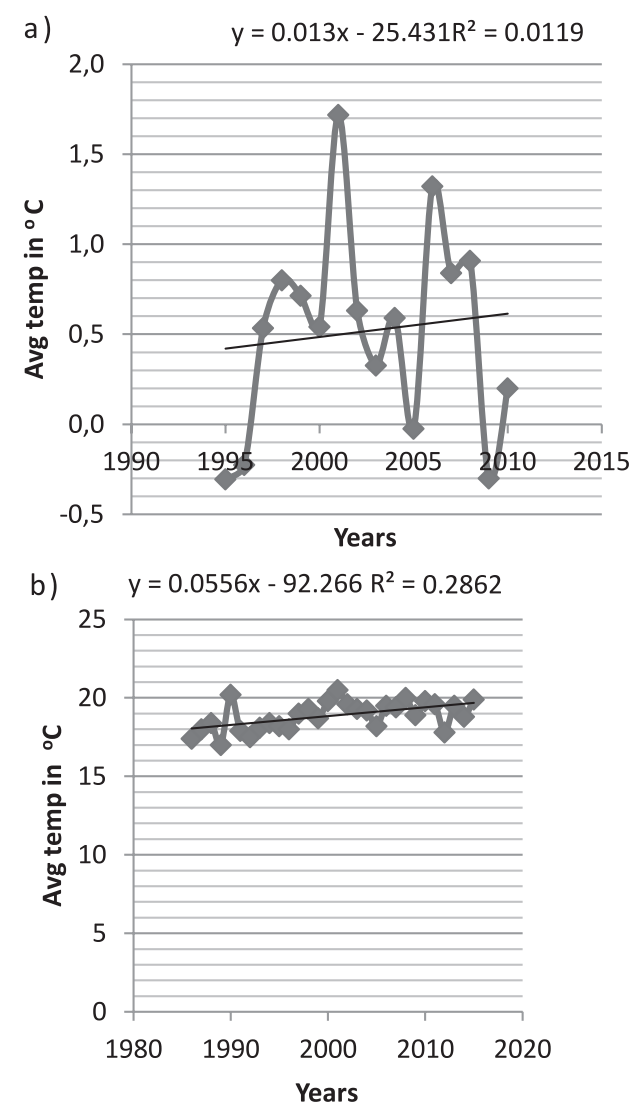

Fig. 2. Trend of mean maximum and minimum temperatures of WAPDA station.
Climate data for the last 30 years was analyzed to find trends of maximum temperature, minimum temperature, and precipitation along the study area. Regression equation and Kendall's tau-b test were applied to find the climate change variability trend for each parameter. Temperature
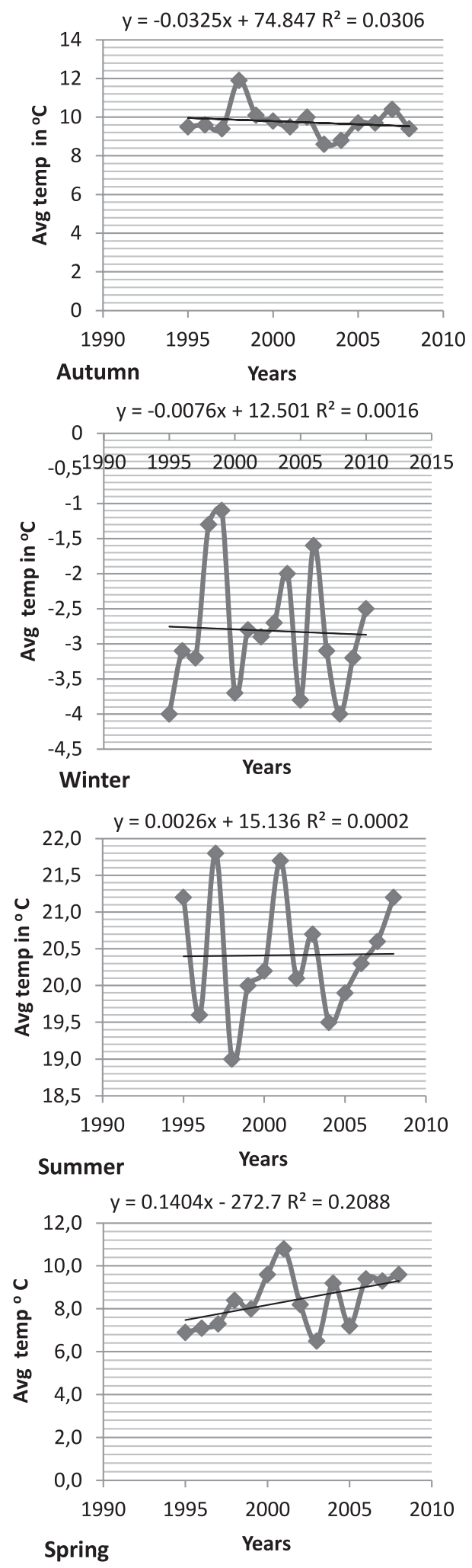

Fig. 3. Trend of mean maximum seasonal temperatures of WAPDA station. 
data of each month were classified (maximum, minimum) for annual and total precipitation data, which were analyzed on an annual basis.

\section{Results and Discussion}

Fig. 2a) depicted the mean minimum temperature as having an increasing trend of $0.02^{\circ} \mathrm{C}$ per year, and a total rise of $0.32^{\circ} \mathrm{C}$ during the study period. The
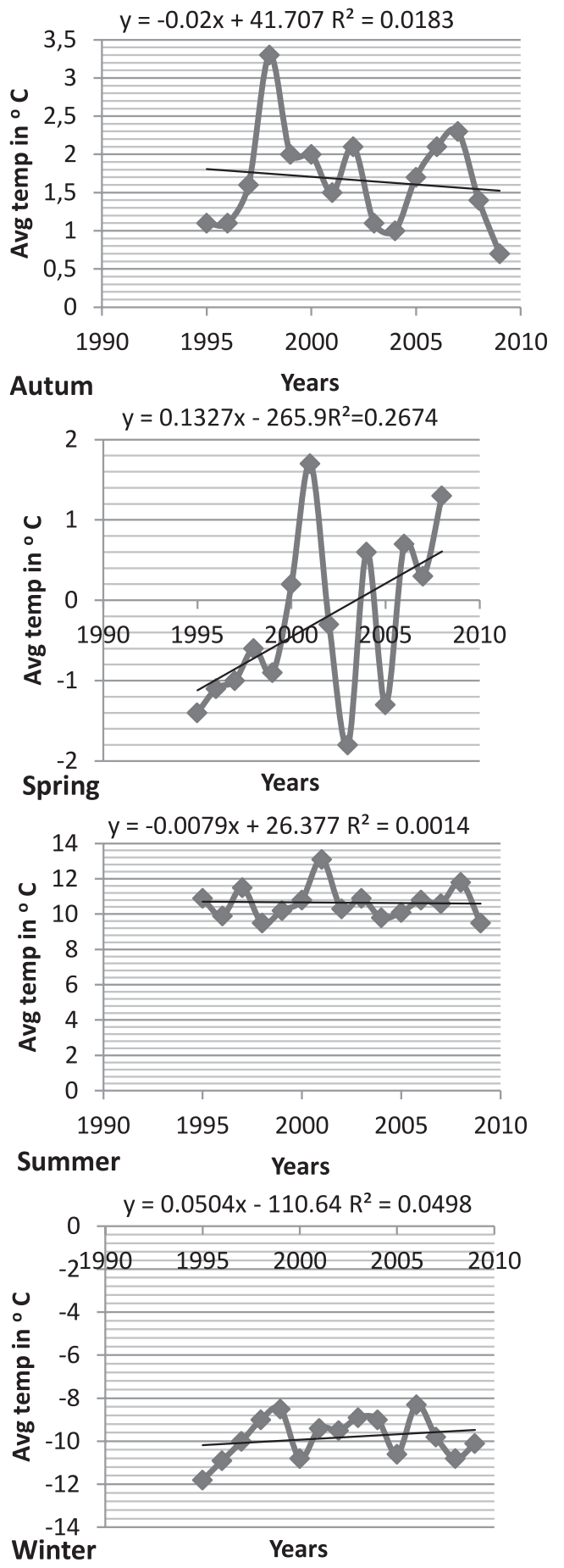

Fig. 4. Trend of mean minimum seasonal temperatures of WAPDA station.
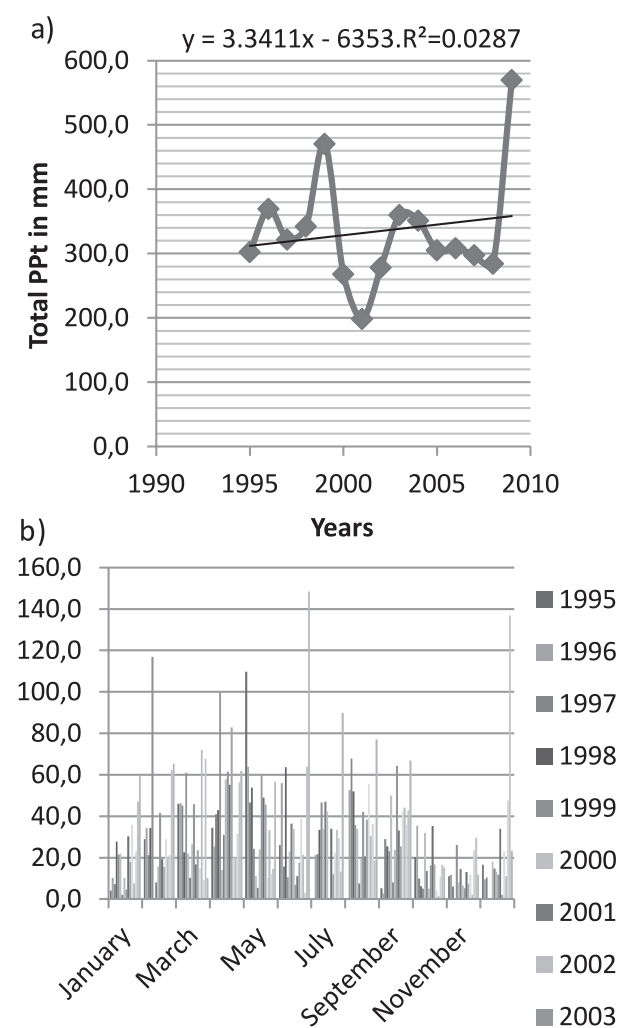

Fig. 5. Trend of annual and monthly precipitation of WAPDA station.

highest minimum temperature of $1.2^{\circ} \mathrm{C}$ was recorded in 2001 and the lowest $--0.3^{\circ} \mathrm{C}$ - during 1995 and 2009. Fig. 2b) revealed that the mean maximum temperature has decreased at a rate of $0.02^{\circ} \mathrm{C}$ per year and during the whole study period it has decreased $0.34^{\circ} \mathrm{C}$. The highest maximum temperature has been recorded simultaneously during 2001, 1998, and 2006, while the lowest maximum temperature was in 2009 . We concluded that overall maximum temperature has a decreasing trend. Fig. 3 shows that the mean maximum temperature on a seasonal base is increasing in spring, while in

Table 1. Trend of annual seasonal mean maximum and minimum temperatures $\left({ }^{\circ} \mathrm{C}\right)$ and precipitation $(\mathrm{mm})$ of WAPDA climatic station using Kendall's tau-b methods.

\begin{tabular}{|c|c|c|c|}
\hline & $\begin{array}{c}\text { Mean } \\
\text { maximum } \\
\text { temperature }\end{array}$ & $\begin{array}{c}\text { Mean } \\
\text { minimum } \\
\text { temperature }\end{array}$ & $\begin{array}{c}\text { Total } \\
\text { precipitation }\end{array}$ \\
\hline Season & $1995-2010$ & $1995-2010$ & $1995-2010$ \\
\hline Annual (J-D) & 0.529 & 0.566 & 0.01 \\
\hline Winter (DJF) & 0.25 & 0.168 & \\
\hline Spring (MAM) & 0.293 & 0.319 & \\
\hline Summer (JJA) & -0.176 & -0.160 & \\
\hline Autumn (SON) & -0.237 & -0.120 & \\
\hline
\end{tabular}

Trend is significant at 0.01 levels. 


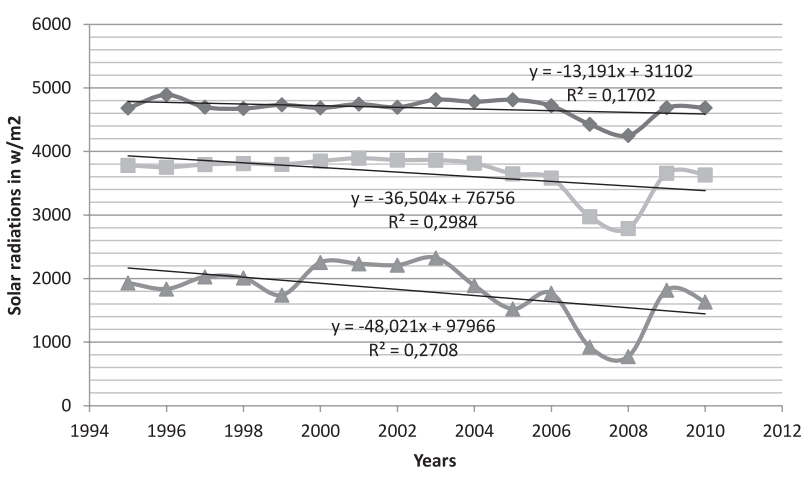

Fig. 6. Trend of annual highest, average, and lowest solar radiation.

summer, autumn, and winter it is more or less constant. Fig. 4 demonstrated mean minimum temperature on a seasonal basis, which increased in winter and spring, while in autumn it slightly decreased, and in summer is more or less constant. Fig. 5a) showed that the total annual precipitation during the study period has increased at a rate of $10.50 \mathrm{~mm}$. Minimum precipitation of $200 \mathrm{~mm}$ was recorded in 2001, while that of maximum precipitation of $700 \mathrm{~mm}$ was recorded in 2010. It is also depicted that with the passage of time the total annual precipitation has increased. Fig. 5b) showed the utmost monthly precipitation occurring in spring, summer, and autumn, respectively, while less precipitation in winter season is recorded in Kendall's tau-b trend to illustrate small but significant variations between annual temperature and different seasons. For maximum temperature, spring has a higher positive correlation than winter, and autumn has a higher negative correlation than summer. Minimum temperatures show that spring has a higher positive correlation than winter, and summer has a higher negative correlation than autumn.

Similarly, the correlation in total precipitation is also significant (Table 1). Fig. 6 illustrates the highest, lowest, and average annual incidences of solar radiation. The highest, lowest, and mean solar incidence has a decreasing trend during the study period, and both have their lowest values in 2008. Highest and lowest solar incidents simultaneously have highest values in 1996 and 2003. Trend analysis of solar radiation showed that there is a negative significant change in average, highest,

Table 2. Trend of annual average, highest, and lowest solar radiation $\left(\mathrm{w} / \mathrm{m}^{2}\right)$ of WAPDA climatic station using Kendall's tau-b methods.

\begin{tabular}{|c|c|c|c|}
\hline & $\begin{array}{c}\text { Highest } \\
\text { solar } \\
\text { radiation }\end{array}$ & $\begin{array}{c}\text { Average } \\
\text { Solar } \\
\text { radiation }\end{array}$ & $\begin{array}{c}\text { Lowest solar } \\
\text { radiation }\end{array}$ \\
\hline Season & $1995-2010$ & $1995-2010$ & $1995-2010$ \\
\hline Annual (J-D) & -0.133 & -0.283 & -0.350 \\
\hline
\end{tabular}

Trend is significant at 0.01 levels.
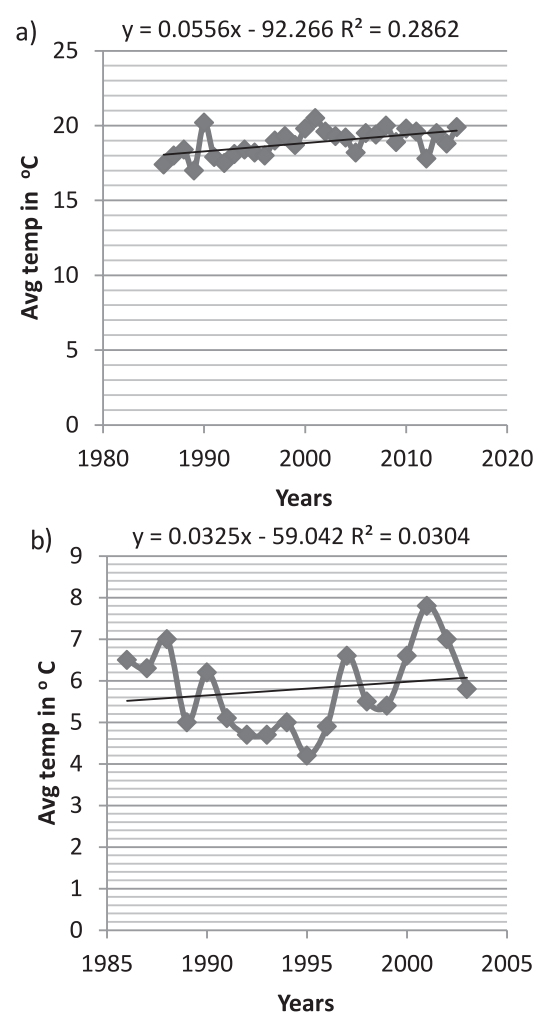

Fig. 7. Trend of annual mean maximum and minimum temperatures of PMD station.

and lowest solar radiations at the annual base (Table 2). Fig. 7a) revealed that the mean maximum temperature has increased, while Fig. 7b) depicts how the minimum temperature has increased during the study period. Both minimum and maximum temperatures have increased with the passage of time over the period 1985-2015. Fig. 8 presents how total annual precipitation during the study period has increased, with minimum precipitation of $82.2 \mathrm{~mm}$ being recorded in 2006 while that of maximum precipitation of $675.6 \mathrm{~mm}$ was recorded in1999. It is also illustrated that with the passage of time the total annual precipitation has increased. Trend analysis of mean, maximum, and minimum temperatures revealed that there is positive moderate correlation between years and temperature and also precipitation (Table 3).

The HKH region is undergoing changes in the cryosphere as a result of climate change. Rising

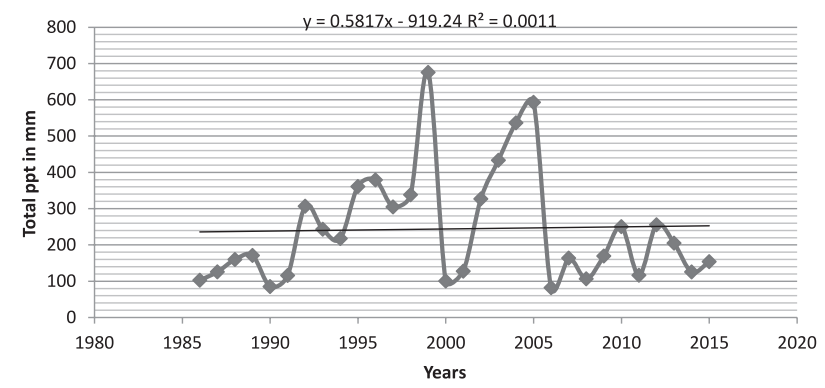

Fig. 8. Trend of annual precipitation of PMD station. 
Table 3. Trend of annual seasonal mean maximum and minimum temperatures $\left({ }^{\circ} \mathrm{C}\right)$ and precipitation $(\mathrm{mm})$ of PMD climatic station using Kendall's tau-b methods.

\begin{tabular}{|c|c|c|c|}
\hline & $\begin{array}{c}\text { Mean } \\
\text { Maximum } \\
\text { Temperature }\end{array}$ & $\begin{array}{c}\text { Mean } \\
\text { Minimum } \\
\text { Temperature }\end{array}$ & $\begin{array}{c}\text { Total } \\
\text { Precipitation }\end{array}$ \\
\hline Season & $1986-2015$ & $1986-2015$ & $1986-2015$ \\
\hline Annual (J-D) & 0.394 & 0.072 & 0.071 \\
\hline
\end{tabular}

Trend is significant at 0.01 levels.

temperatures and changing precipitation patterns across the $\mathrm{HKH}$ region resulting from climate change have an influence on water resource availability and food security for the downstream population. Predicted increases in temperature will drive increased shrinkage of glaciers [18]. While in the eastern $\mathrm{HKH}$ region glaciers are retreating at smaller rates than previously estimated [19], and there is still uncertainty in estimating glacial retreat. The rates of retreat in the HKH region are not implicit because of a lack of field data [20], making it complex to understand the impact of regional climate change [21]. A number of recent studies have demonstrated that $\mathrm{HKH}$ glaciers have experienced negative mass balance overall in the last decade [22]. A study by Fujita and Nuimura [23] looking at three benchmark glaciers found evidence of rapid glacier wastage since the 1970s. Especially lower glaciers have a more negative mass balance than the arid high-elevation benchmark glacier, implying that the lower glaciers are more sensitive to change. Black carbon deposition in Tibetan glaciers may have contributed to their fast retreat [24]. Most of the glaciers in the HKH region have been retreating and losing mass since the mid-19th century [25].

Glacier mass balances are declining significantly in the Hindu Kush and Spiti-Lahaul regions to positive values in the Pamir-Karakoram-western-Kunlun-Shan region. This proposes the so-called Karakoram glacier mass-balance anomaly, or Pamir-Karakoram anomaly [26]. A study using satellite altimetry data disclosed a complex pattern in mass balance with the Karakoram glaciers thinning by only a few centimeters a year with greater rates of loss in the Hindu Kush and the central and eastern Himalayas [26]. Potential consequences of glacier changes would mean unsustainable water supplies from major rivers, which might threaten the livelihoods and well being of those in the downstream regions [2730]. Due to a general increase in warming, stored water has started melting at an accelerating rate due to the rising formation of new glacial lakes, and local floods are due to glacial lake outburst floods [31]. The melting rates of low-elevation glaciers are faster due to the increasing trend of temperature from lower elevations to higher ones, consequently accelerating the melting rates of glaciers and causing the formation of visible supra- and sub-glacial lakes in the Hindu Kush, Karakorum, and Himalaya glaciers, which also revealed a snowline shift about $1 \mathrm{~km}$ higher than its location 25 years ago [9]. A current assessment of HKH glaciers using a combination of remote sensing and in situ data found diverse patterns of glacial retreat within the region [32]. The concentration of greenhouse gases (GHGs) has considerably increased throughout the last few decades because of anthropogenic activities such as burning of fossil fuels and biomass, rapid industrialization, land use changes, and deforestation. This increased GHG concentration has a consequence in global warming and a global energy imbalance [3334]. In the present investigation a detailed questionnaire study was carried out in July 2016 to record the ground observations of climate variability along Darkut Valley. According to the local inhabitants, Darkut Glacier has significantly shrunken in last 2-3 decades. Before the said period, the area received 1-3 $\mathrm{m}$ of snowfall, but today the amount hardly reaches $1 \mathrm{~m}$. The study also reported that a varied rain pattern has been observed with a significant increase of summer rain. Besides, a glacial lake has formed behind the terminal moraine (Fig. 1c). As confirmed by the local inhabitants, that lake formed 20 to 30 years ago and changes are also experienced in Darkut Glacier by repeating coordinate measurements of the snout carried out between 2013 and 2016 (Fig. 1b).

HKH climate is heavily controlled by three circulation systems that are largely responsible for the patterns of seasonal precipitation in the region [35]. The western disturbances bring snowfall during the winter and preIndian Summer Monsoon months [36-37]. Although there is less of a gradient in total snowfall along the HKH arc, there is a difference in the seasonal timing of snowfall [38]. Local climate determines the rate at which seasonal snow varies to glacier ice [39]. The western disturbances intermittently bring moisture over the UIB, mainly in solid form throughout the year, though their main input comes during winter and spring [40-42]. Glaciers controlled by the summer monsoon (i.e., east of the SpitiLahaul) illustrated thickness losses, meaning summer accumulation-type glaciers [43-44]. Glaciers with considerable winter accumulation are under the influence of the westernlies, establishing a more mixed picture with stable or growing thicknesses in the Karakoram and western Kunlun Shan, but thickness losses - for instance in the Hindu Kush. Maximum precipitation occurs in the Upper Indus Basin during the winter and spring seasons due to the westernlies [45-46]. Fluctuations in the Upper Indus Basin Glacier are most probably due to precipitation rather than thermal anomalies [47]. The variability of snowfall rate and intensity during spring/summer has a significant impact on glacial mass balance. The timing and amount of snowfall in the early ablation (mass loss) season is a key process for the surface energy balance of glaciers and irregular events effects that can continue during the entire ablation season [48-50]. Similarly, in our study it is demonstrated that the variabilities occurred in seasonal precipitation as less precipitation occurred in winter and spring, and more precipitation occurred in summer and autumn in the eastern Hindu Kush, which have negative repercussions on Darkut Glacier. 
In the past 30 years temperature have increased in mountainous regions of Pakistan as a result of increasing melting rates for snow and glaciers [51]. The winter warming and summer cooling trends are less common than previously thought [52-53]. By analyzing temperature, Río et al. [54] also described dominant warming during March and the pre-monsoonal period instead of the winter season. The analysis from the above-mentioned studies are mostly based on low-altitude stations of PMD [55]. Contrary to these low-altitude stations, high altitudes in South Asia mainly feature opposite signs of climatic change and extremes, possibly controlled by local factors [56]. While long-term warming at minimum temperature is restricted during February-May and in November, which dominates during March and February and is prominent at higher altitude stations than low altitude [57]. A decrease of solid precipitation due to higher temperatures in winter is expected to have an effect only on lower reaches of glaciers, while the impact of summer cooling is widespread at all elevations and the winter warming effect is restricted to lower elevations only [58].The rate of warming in annual mean surface air temperature in China was $0.25-1^{\circ} \mathrm{C}(10 \mathrm{yr})$ through $1951-2004$, when most significant warming happened in spring and in winter in northern China and over the Qinghai-Tibetan Plateau [59]. The trend analysis under the RCP emission scenarios demonstrated that the temperature in the Gilgit catchment will raise significantly (approximately $3-10^{\circ} \mathrm{C}$ ) due to the excessive increase in the concentrations of greenhouse gases in the atmosphere by the end of the $21 \mathrm{st}$ century [60]. The annual mean temperature will increase by approximately $3^{\circ} \mathrm{C}$ in 90 years, from 2011 to 2100 , in the Gilgit catchment, while summer temperatures will decrease at the Gilgit, Yasin, Gupis, and Ushkore stations, respectively, from 2011 to 2100 [61]. We found a contrast between summer and winter temperatures with significant increases in winter mean and maximum temperatures, and a constant decline in summer mean and minimum temperatures from 1961 to 2000 in sub-catchments of UIB [61]. The annual and seasonal minimum, maximum, and mean temperatures have increased significantly since 1986 in the Gilgit catchment. The increase in spring flows was high compared with the annual and other seasonal flows due to significant increases in spring temperature [62]. In our study low elevation PMD station (2,155 m) data (1986-2015) shows that annual mean maximum and minimum temperatures increased and high elevation (3,150 m) WAPDA station data (1995-2010) depicted that annual mean maximum temperature is in slight decline and minimum temperature increased, while seasonal data shows an increase in spring temperature while winter is slightly increased or more or less constant, and autumn is in slight decline, while summer is more or less constant.

Thermal radiation and surface solar radiation (SSR) have diverse effects on temperature, and are slightly decreased in the annual mean maximum temperature during 1961-89, which was consistent with the decrease in
SSR as recorded [63]. While the minimum temperature, which was little influenced by total SSR, was increasing during this period, suggesting that the greenhouse effect was enhanced [64]. The SSR also had influences on the surface temperature in China while the greenhouse effect was still the major driver of surface temperature rises. The correlation coefficient between SSR and DTR was the highest in winter, which indicates that total SSR had the largest influence on DTR in winter, showing that the solar radiation effect on DTR was the largest in this season [64]. Similar results are also observed in our study, including a decreasing trend in total annual solar radiations as a result of decreasing mean maximum temperature, while mean minimum temperature is increased because surface solar radiation has little influence on minimum temperature, which has negative repercussions on the study area glacier.

\section{Conclusions}

Mean maximum temperature was more or less in decline in 1995-2010 as annual mean minimum temperature increased, while data for the period 19862015 shows an increasing trend of both mean maximum and minimum temperatures. Seasonal mean maximum and minimum temperatures increased and temperatures in autumn and summer remained slightly constant. However, in the same period precipitation data shows that most precipitation occurred in late spring, summer, and autumn, and less in winter, but overall precipitation trend increased in the study period. Solar radiation has greatly influenced mean minimum temperature and also winter and spring. In addition to greenhouse gases, anthropogenic activities and fossil fuel aerosols deriving surface temperature may also be affected. Nevertheless, both stations have similar results except for the high elevation WAPDA station, which observed a slight decline in maximum temperature. The increasing temperature trend in winter and spring and decreasing precipitation in winter and early spring caused earlier and faster snow melt. As a result of the enhanced melting rate of Darkut Glacier and the glacier lake formation behind the terminal moraine, the glacier retreated $6 \mathrm{~m}$ during 2013 and 2016. So, further detailed investigation is necessary for understanding the behavior of glaciers under the climate change scenario in the future.

\section{Acknowledgements}

This research is part of an MPhil degree program. The authors are grateful to NORHED-SUNREM Himalaya Project for financial support, and are thankful to WAPDA and PMD for providing the essential climate data. The authors are also very grateful to the anonymous reviewers for their valuable comments. 


\section{References}

1. FAROOQI A.B., KHAN A.H., MIR H. Climate Change Perspective in Pakistan. Pakistan J Meteorology, 2005.

2. HUSSAIN S., MUDASSER M., SHEIKH MM., MANZOO N. Climate change and variability in mountain regions of Pakistan implications for water and Agricultural. Pak. J. Meteorol. 2 (4), 2005.

3. IPCC. Summary for Policymakers. In: Climate Change:The Physical Science Basis. Contribution of Working GroupI to the Fifth Assessment Report of the Intergovernmental Panel on Climate Change [Stocker T.F., Qin D., PlattnerG.K., Tignor M., Allen S.K., Boschung J., Nauels A., XiaY., Bex V., and Midgley P.M (eds.)]. Cambridge UniversityPress, Cambridge, United Kingdom and New York, NY,USA, 2013.

4. BOOKHAGEN B., BURBANK D.W. Toward a complete Himalayan hydrological budget: Spatiotemporal distribution of snowmelt and rainfall and their impact on river discharge[M]// Journal of Geophysical Research: Earth Surface (2003-2012), 2010.

5. IMMERZEEL W.W., BEEK L.P.H., BIERKENS M.F.P. Climate change will affect the Asian water towers. Science 328, 1382, 2010.

6. BOCCHIOLA D., DIOLAIUTI G. Recent (1980-2009) evidence of Climate Change in the Upper Karakoram, Pakistan. Theoretical and Applied Climatology, 113, 611, 2013.

7. MATSUO K., HEKI K. Time Variable ice Loss in Asian High Mountains from the Satellite gravimetry. Earth and Planetary Science Letters, 290 (1-2), 30, 2010.

8. HEWITT K. Glacier change, concentration, and elevation effects in the Karakoram Himalaya, Upper Indus Basin, Mount. Res. Develop., 31, 188, 2011.

9. RASUL G., CHAUDHRY Q.Z. Global Warming and Expected Snowline Shift along Northern Mountains of Pakistan. Proc. of 1st Asiaclic Sympos. Yokohama, Japan, 2006.

10. BARRY R.G. Changes in Mountain Climate and Glaciohydrological Responses. Mountain Research Development. 10, 161, 2002.

11. RASUL G., MAHMOOD A.S., KHAN A. Vulnerability ofthe Indus Delta to Climate Change in Pakistan. Pakistan Journal of Meteorology, 8 (16), 89, 2012.

12. IMMERZEEL W.W., PELLICCIOTTI F., BIERKENS M.F.P. Rising river flows throughout the twenty first centuryin two Himalayan glacierized watersheds. Nature Geoscience 6, 742, 2013.

13. WILD M. Global dimming and brightening: A review. J. Geophys. Res., 114, D00D16, doi: 10.1029/2008JD011470, 2009.

14. MAKOWSKI K., WILD M., OHMURA A. Diurnal temperature range over Europe between 1950 and 2005. Atmos. Chem. Phys., 8, 6483, 2008.

15. SCHERLER D., BOOKHAGEN B., STRECKER MR. Spatially variable response of Himalayan glaciers to climate change affected by debris cover. Nature Geosci., 4 (3), 156, 2011.

16. KARGEL J.S., COGLEY J.G., LEONARD G.J., HARITASHYA U., BYERS A. Himalayan Glaciers: The Big Pictures is a Montage. Proceedings of the National Academy of Sciences of the United States of America 108 (36), 14709, 2011.

17. HASSON S., LUCARINI V., KHAN M. R., PETITTA M., BOLCH T., GIOLI G. Early $21^{\text {st }}$ century snow cover state over the western river basins of the Indus River system, Hydrol. Earth Syst.Sci., 18, 4077, 2014b.

18. MILLER J.D., IMMERZEEL W.W., REES G. Climate Change Impacts on Glacier Hydrology and River Discharge in the Hindu Kush-Himalayas, Mountain Research and Development, 32 (4), 461, 2012.

19. JACOB T., WAHR J., PFEFFER W.T., SWENSON S Recent contributions of glaciers and ice caps to sea level rise, Nature, 482, 514, 2012.

20. THOMPSON L.G. Climate Change: The Evidence and Our Options. The Behavior Analyst 33 (2), 153, 2010.

21. SCHERLER D., BOOKHAGEN B., STRECKER M. R. Spatially Variable Response of Himalayan Glaciers to Climate Change Affected by Debris Cover. Nature Geoscience 4, 156, 2011b.

22. GARDNE A.S., MOHOLDT G., COGLEY J.G., WOUTERS B., ARENDT A.A., WAHR J., BERTHIER E., HOCK R., PFEFFER W.T., KASER G., LIGTENBERG S.R.M., BOLCH T., SHARP M.J., HAGEN J.O., VAN DEN BROEKE M.R., PAUL F. A Reconciled Estimate of Glacier Contributions to Sea Level Rise: 2003 to 2009, Science, 340, 852, 2013.

23. FUJITA K., NUIMURA T. Spatially heterogeneous wastage of Himalayan glaciers, P. Natl. Acad. Sci. USA, 108, 14011, 2011.

24. XU B., J. CAO J., HANSEN T., YAO D. R., JOSWIA N., WANG G., WU M., WANG H., ZHAO W., YANG X., LIU J. HE. Black Soot and the Survival of Tibetan Glaciers, Proceedings of the National Academy of Sciences of the United States of America 106 (52), 22114, 2009.

25. BOLCH T., KULKARNI A., KÄÄB A., HUGGEL C., PAUL F., COGLEY J.G., FREY H., KARGEL J.S., FUJITA K., SCHEEL M., BAJRACHARYA S., STOFFEL M. The state and fate of Himalayan glaciers, Science, 336, 310, 2012.

26. GARDELLE J., BERTHIER E., ARNAUD Y. Slight mass gain of Karakoram glaciers in the early 21 st century, Nat. Geosci. 5, 322, 2012a.

27. HEWITT K. Glacier change, concentration, and elevation effects in the Karakoram Himalaya, Upper Indus Basin, Mount. Res. Develop., 31, 188, 2011.

28. KÄÄB A., BERTHIER E., NUTH C., GARDELL J., ARNAUD Y. Contrasting patterns of early twenty firstcentury glacier mass change in the Himalayas, Nature, $\mathbf{4 8 8}$, 495, 2012.

29. IMMERZEEL W.W., BEEK L.P.H., BIERKENS M.F.P. Climate change will affect the Asian water towers. Science 328, 13822010.

30. KASER G., GROŸHAUSER M., MARZEION B. Contribution potential of glaciers to water availability in different climate regimes. Proc. Natl Acad. Sci. USA 107, 20223, 2010.

31. CHAUDHRY Q.Z., RASUL G. Development of a mesoscale convective system over the foot hills of Himalaya into a severe storm. Development in Earth sciences processes 10, 301, 2007.

32. YAO T., THOMPSON L., YANG W., YU W., GAO Y., GUO X., YANG X., DUAN K., ZHAO H., XU B., PU J., LU A., XIANG Y., KATTEL D. B.,JOSWIAK D. Different glacier status with atmospheric circulations in Tibetan Plateau and surroundings, Nature Clim. Change advance online publication, 2012.

33. LIU B. H., XU M., HENDERSON M. Taking China's temperature: Daily range, warming trends, and regional variation, 1955-2000. J.Climate, 17 (22), 4453, 2004. 
34. CHU J., XIA J., XU C.Y., SINGH V. Statistical downscaling of daily mean temperature, pan evaporation and precipitation for climate change scenarios in haihe river, China. Theor. Appl. Climatol. 99, 149, 2010.

35. WILTSHIRE A.J. Climate change implications for the glaciers of the Hindu-Kush, Karakoram and Himalayan region [J]. Cryosphere, 8 (3), 941, 2014.

36. BOOKHAGEN B., BURBANK D W. Topography, relief, and TRMM-derived rainfall variations along the Himalaya [J]. Geophysical Research Letters, 33 (13), 153, 2006.

37. BOOKHAGEN B., BURBANK D.W. Toward a complete Himalayan hydrological budget: Spatiotemporal distribution of snowmelt and rainfall and their impact on river discharge[M]// Journal of Geophysical Research: Earth Surface (2003-2012), 2010.

38. FUJITA K. Influence of precipitation seasonality on glacier mass balance and its sensitivity to climate change, Ann. Glaciol., 48, 88, 2008b.

39. CUFFEY K.M., PATERSON W.S.B. The Physics of Glaciers, Fourth Edition, Burlington, MA: ButterworthHeinemann, Elsevier, 2010.

40. RIDLEY J., WILTSHIRE A., MATHISON C. More frequent occurrence of westerly disturbances in Karakoram up to 2100, Sci. Total Environ., 468-469, S31, 2013.

41. HASSON S., LUCARINI V., PASCALE S. Hydrological cycle over South and Southeast Asian river basins as simulated by PCMDI/CMIP3 experiments, Earth Syst. Dynam., 4, 199, 2013.

42. HASSON S., BÖHNER J., LUCARINI V. Prevailing climatic trends and runoff response from HindukushKarakoram-Himalaya, upper Indus basin, Earth Syst. Dynam. Discuss, 6, 579, 2015.

43. KAPNICK S.B., DELWORTH T.L., ASHFAQ M., MALYSHEV S., MILLY P.C.D. Snowfall less sensitive to warming in Karakoram than in Himalayas due to a unique seasonal cycle, Nat. Geosci., 7, 834, 2014.

44. MAUSSION F., SCHERER D., MÖLG T., COLLIER E., CURIO J., FINKELNBURG R. Precipitation seasonality and variability over the Tibetan Plateau as resolved by the High Asia Reanalysis, J. Climate, 27, 1910, 2014.

45. DIMRI A.P., YASUNARI T., WILTSHIRE A., KUMAR P.,MATHISON C., RIDLEY J., MATHISON C., JACOB D. Application of regional climate models to the Indian winter monsoon over the western Himalayas. Science of Total Environment, 468, 2013.

46. DIMRI A.P., CHEVUTURI A. Model sensitivity analysis study for western disturbances over the Himalayas. Meteorology and Atmospheric Physics, 123, 2014.

47. SARIKAYA M.A., BISHOP M.P., SHRODER J.F.,OLSENHOLLER J.A. Space based observations of Eastern Hindu-Kush glaciers between 1976 and 2007, Afghanistan and Pakistan. Remote Sensing Letters, 3 (1), 77, 2012.

48. MÖLG T., SCHERER D. Retrieving important massbalance model parameters from AWS measurements and higher solution mesoscale atmospheric modeling. J. Glaciol., 58, 625, 2012.

49. YANG W., GUO X., YAO T., YANG K., ZHAO L., LI S., ZHU M. Summertime surface energy budget and ablation modelling in the ablation zone of a maritime Tibetan glacier. J. Geophys. Res. 116, D14116, 2011.

50. YANG W., YAO T., GUO X., ZHU M., LI S., KATTEL D. B. Mass balance of a maritime glacier on the southeast
Tibetan Plateau and its climatic sensitivity. J. Geophys. Res. Atmos., 118, 9579, 2013.

51. HUSSAIN S., MUDASSER M., SHEIKH MM., MANZOO N. Climate change and variability in mountain regions of Pakistan implications for water and Agricultural. Pakistan Journal of Meteorology 2 (4), 2005.

52. BOCCHIOLA D., DIOLAIUTI G. Recent (1980-2009) evidence of climate change in the upper Karakoram, Pakistan, Theor. Appl. Climatol., 113, 611, 2013.

53. SCHERLER D., BOOKHAGEN B., STRECKER MR. Spatially variable response of Himalayan glaciers to climate change affected by debris cover. Nature Geosci., 4 (3), 156, 2011.

54. RÍO S.D., IQBAL M.A., CANO-ORTIZ A., HERRERO L., HASSAN A., PENAS A. Recent mean temperature trends in Pakistan and links with teleconnection patterns, Int. J. Climatol., 33, 277, 2013.

55. HASSON S., PASCALE S., LUCARINI V.,BÖHNER J. Seasonal cycle of precipitation over Major River Basins in South and Southeast Asia: a review of the CMIP5 climate models data for present climate and future climate projections, J. Atmos. Res., in review, 2015.

56. REVADEKAR J.V., HAMEED S., COLLINS D., MANTON M., SHEIKH M., BORGAONKAR H.P.,KOTHAWALE D. R., ADNAN M., AHMED A.U., ASHRAF J., BAIDYA S., ISLAM N., JAYASINGHEARACHCHI D., MANZOOR N., PREMALAL K.H.M.S., SHRESHTA M.L. Impact of altitude and latitude on changes in temperature extremes over South Asia during 1971-2000, Int. J. Climatol., 33, 199, 2013.

57. HASSON S., BÖHNER J., LUCARINI V. Prevailing climatic trends and runoff response from HindukushKarakoram-Himalaya, upper Indus basin, Earth Syst. Dynam. Discuss, 6, 579, 2015.

58. ARCHER, FOWLER H.J. Conflicting Signals of Climatic Change in the Upper Indus Basin, Journal of Climate,19, 2005.

59. REN G., MINGZHI X., ZIYING C. Changes of surface air temperature in China during 1951-2004. Clim. Environ. Res. 10 (4), 717, 2005c.

60. IPCC: Summary for Policymakers. In: Climate Change 2013: The Physical Science Basis. Contribution of Working GroupI to the Fifth Assessment Report of the IntergovernmentalPanel on Climate Change [Stocker T.F., Qin D., PlattnerG.K., Tignor M., Allen S.K., Boschung J., Nauels A., XiaY., Bex V., and Midgley P.M (eds.)]. Cambridge UniversityPress, Cambridge, United Kingdom and New York, NY,USA, 2013.

61. IQRA A., IQBAL J., MAHBOOB M.A. Modeling massbalance of Upper Indus Basin glaciers in relation withclimatic variability. Sci. Int. (Lahore), 28 (3), 2637, 2016.

62. ADNAN M., NABI G., KANG S., ZHANG G., ADNAN M.R., ANJUM N.M., IQBAL M., ALI F.A. Snowmelt Runoff Modelling under Projected Climate Change Patterns in the Gilgit River Basin of Northern Pakistan. Pol. J. Environ. Stud. 26 (2), 525, 2017.

63. WILD M., OHMURA A., MAKOWSKI K. Impact of global dimming and brightening on global warming. Geophys. Res. Lett. 34, L04702, 2007.

64. ZHANG H., QING Y., NAKAJIMA T. Influence of changes in solar radiation on changes of surface temperature in China. Acta Meteor. Sinica. 27 (1), 87, 2013. 